\title{
Gauging the Investment Potential of International Real Estate Markets
}

\author{
A Paper Presented at the Annual \\ European Real Estate Society Meeting (ERES) \\ Dublin, Ireland \\ Stephen Lee \\ Centre for Real Estate Research (CRER), \\ Department of Real Estate and Planning, \\ Business School, \\ The University of Reading, \\ Reading RG6 6AW, England
}

Phone: +44 118931 6338, Fax: +44 118931 8172, E-mail: S.L.Lee@reading.ac.uk

\begin{abstract}
Investing in real estate markets overseas means venturing into the unknown, where you meet unfamiliar political and economic environments, unstable currencies, strange cultures and languages, and so although the advantages of international diversification might appear attractive, the risks of international investment must not be overlooked. However, capital markets are becoming global markets, and commercial real estate markets are no exception, accordingly despite the difficulties posed by venturing overseas no investor can overlook the potential international investment holds out. Thus, what strategies are appropriate for capitalising on this potential? Three issues must be considered: (1) the potential of the countries real estate market in general; (2) the potential of the individual market sectors; and (3) the investment process itself. Although each step in foreign real estate investment is critical, the initial assessment of opportunities is especially important. Various methods can be used to achieve this but a formal and systematic analysis of aggregate market potential should prove particularly fruitful. The work reported here, therefore, develops and illustrates such a methodology for the over 50 international real estate markets.
\end{abstract}

Keywords: Market Potential, Risk and Return Factors 


\section{Gauging the Investment Potential of International Real Estate Markets}

\section{Introduction}

International real estate investments are made in a foreign country's property market in order to reduce the investor's portfolio risk. Such investment risk reduction is possible because real estate markets of different countries generally have low levels of correlation (see Sweeny, 1988, 1989; Chua, 1999; Conover et al, 2002; and Baum, 1999 among others). Such low correlations are attributed to differences in return behaviour over time stemming from different market structures and idiosyncratic economic shocks. In addition, real estate investments overseas may help investors increase returns. For example, during the period 1985-1995 Pagliari et al (1997) found that office property investments in the US during that period provided a zero average annual return while similar investments in UK, Australia, and Canada provided an average annual return as high as $12.4 \%, 8.1 \%$, and $4.5 \%$, respectively. Consequently, a number of industry studies produced by major investment advisors including Henderson (2000), Prudential (1988 and 1990) and AIG (2001) have all advocated that international real estate should be the next frontier for the real estate investor. Indeed, Webb and O'Keefe (2002) suggest that there are only 14 countries in the world that have real estate markets of sufficient size to provide domestic investors with a unique asset class, while the rest of the world must invest internationally to have access to sufficient investment grade real estate to incorporate into their mixed-asset portfolio. Thus, in their opinion international investment is now an essential part of the real estate portfolio construction process.

However, investing in real estate markets overseas means venturing into the unknown, where you meet unfamiliar political and economic environments, unstable currencies, strange cultures and languages, and so although the advantages of international diversification might appear attractive, the risks of international portfolio investment must not be overlooked, see Sirmans and Worzala (2000) and Kateley (2002). Nonetheless, capital markets are becoming global markets and commercial real estate markets are no exception so despite the difficulties posed by venturing overseas, no investor can overlook the potential international real estate investment holds out. However, what strategies are appropriate for capitalising on this potential? Three issues must be considered: (1) the potential of the countries real estate market in general; (2) the potential of the individual market sectors (retail, office industrial etc.) within the country; and (3) the investment process itself (direct, indirect, joint venture etc.). Although each step in foreign real estate investment is critical, the initial assessment of opportunities is especially important. Various techniques can be used, such as gathering background information (desk research), making individual assessments based on contacts with local investors and monitoring competitor activity. A formal and systematic analysis of each countries market potential should be particularly fruitful (Arnold and Grossman, 1995), however, with few exceptions very little work as been done in this area. This paper sets out to correct this position by developing and illustrating a methodology for quantifying the investment potential of international real estate markets for over 50 countries across the world. 
The remainder of the paper is organised as follows. The next section outlines the characteristics of markets investors will need to analyse when considering international real estate investment. Section 3 discusses the data used to represent the characteristics. Section 4 presents the REP Index and discusses its' uses and limitations. Section 5 concludes the paper and suggests future areas of research.

\section{The Investment Characteristics of International Real Estate Markets}

In the equity and bond markets there is abundant literature on the benefits of international diversification (see Madura, 1985 and Lonie et al. 1993 for extensive reviews). These studies clearly indicate that the risk and return advantages of international diversification are very large for investors. In contrast, Wilson and Zurbruegg (2003) argue that currently, there is no consensus on how much benefit can be derived from diversifying real estate portfolios globally, irrespective of whether direct or indirect property assets are being examined, although the research results are generally encouraging. However, real estate investors, unlike equity and bond investors, face major informational problems when contemplating international investment such as: differences in property rights and economic efficiency (Jaffe and Louziotis, 1996); differences in market maturity (Keogh and D'Arcy, 1994); differences in size, accessibility and security of tenure (Sweeney, 1993) and differences in property taxes, the recoverability of out goings, and the exit liquidity (PRICOA, 1998). It is surprising therefore to find that with the notable exceptions of the work by Geurts and Jaffe (1996); Levine (2004); Lee (2001, 2004); Liao and Mei (1999); Shun (2004) and Chen and Hobbs (2003) few studies have tried to compare the investment characteristics of international real estate markets.

Geurts and Jaffe (1996) examined a number of economic as well as so-called "non economic" risks of 32 countries to see if such factors are associated with investing in certain countries. These categories are: (a) Risk Assessment Variables, (b) Property Rights Variables, (c) Socio-cultural Factors, and (d) Foreign Investment Variables. Geurts and Jaffe (1996) however do not examine the impact of such factors on the real estate returns.

Lee (2001, 2004) expands on the work of Geurts and Jaffe (1996) and examines four country-specific risks faced by investors; political risk, market maturity, transparency and corruption for 28 countries to see if any these features can explain the reluctance of investors to venture overseas. Lee $(2000,2004)$ argues that the key barrier faced by real estate investors is the acquisition of appropriate local market information as different countries display differing administrative, legislative and fiscal regimes, coupled with differing property market conventions and codes of valuation practice. In particular, Lee (2001, 2004) concludes that when overseas investment is considered it is clear that institutional real estate investors, other things being equal, will opt to invest in the most transparent, mature and least corrupt markets whenever they can.

A book edited by Levine (2004) purports to provide a comparative analysis of 33 real estate markets across the world, however, the comparative analysis is confined to two appendices the first presenting a few charts showing the differences in GDP; population 
etc. between countries, while the second gives an out of date table providing simple indicators of economic stability, individual safety; difficulties of ownership etc. In other words, a quick summary of the countries which is little more than that covered in the CIA Factbook augmented with some data on the legal issues affecting real estate.

Liao and Mei (1999) examined whether differences in economic variables, such as GDP growth the countries risk rating, and institutional factors such as the level of economic freedom impact property returns and risks. Using security market data from 24 developed and emerging markets, the results show that institutional factors do indeed influence real estate returns and these factors may not be fully priced. In particular, Liao and Mei (1999) find that after controlling for return volatility and the level of economic growth, a higher property return is expected in countries where the economy is more efficient and has more economic freedom, supporting the arguments of Lee $(2001,2004)$.

La Porta et al (1997) argue that of the four legal systems in the world (English, French, German and Scandinavian) the English common law system is the most suitable to enhance capital market development, while the French system is the least attractive. Shun (2004) uses this idea to examine the impact of the "Rule of Law" on real estate security returns. Using property shares returns data from 23 countries Shun (2004) hypothesis that countries following the English system will show greater risk-adjusted performance that countries following the French civil code. Using ANOVA methodology Shun (2004) found that at the individual country level there was a highly significant difference in the mean returns between countries in the four legal traditions, with the countries that had adopted the English system of common law showing the highest riskadjusted performance.

Chen and Hobbs (2003) build on the earlier work of Geurts and Jaffe (1996); Liao and Mei (1999) and Lee (2001, 2004) and develop a Global Real Estate Risk (GRER) index for 44 countries based on three components; country, structural and cyclical real estate risks. The authors arguing that these three measure capture the key dimensions of international real estate risk. However, due to the propriety nature of the work the authors provide little or no information on individual countries and only summaries the results by ranking the countries as either "Opportunistic” or "Core”.

As the present work is the closest in approach and data coverage as that of Chen and Hobbs (2003) we outline a number of differences and similarities between this study and their work. First, Chen and Hobbs (2003) use a large number of data sources in developing their index, most of which are not sourced or are propriety in nature. The data used here is available for others to use or expand. Second, Chen and Hobbs (2003) use principle components analysis (PCA) to reduce their diverse data down to the three manageable dimensions of risk and use the results from the PCA to weight their overall GRER index. In this study we use equal weighting to derive the overall REP index for illustrative purposes only, as it seems reasonable to expect that the weight of each dimension may have to be revised for different investors and circumstances. Third, although not stated it appears that the Country Risk Index used by Chen and Hobbs (2003) was based on data from one of the country risk rating organisation such as: 
Euromoney; the International Country Risk Guide (ICRG) or the Economist Intelligence Unit (EIU) ratings, which are available by subscription or through publications. We use the Euromoney ratings as these are the easiest to access by all investors. Fourth, Chen and Hobbs (2003) calculate a Structural Risk index using information on maturity; institutional risk (essentially size) and investment risk (market volatility). The Market Specific Risk measure derived here is based on essentially the same data sources ${ }^{1}$. Fifth, we do not include real estate returns data into the analysis as such data is generally unavailable on a consistent basis or is only available for a short time period. We therefore proxy expected returns by the average expected growth in GDP over the next five years. Six, we use the Jones Lang LaSalle (JLL) Global Real Estate Transparency (GRET) Index (2004) as a standalone measure the transparency of the countries real estate market, whereas Chen and Hobbs (2003) subsume their measure of transparency into use their Structural Risk index. The Cyclical Risk index developed by Chen and Hobbs (2003) which categories each countries position on the real estate clock has no comparable measure here as we argue that this is a second level decision once the investor has ascertained that the country is worthy of further investigation. Seven, we incorporate data to reflect the taxation and ownership issues relating to direct real estate investment, which is lacking in the Chen and Hobbs (2003) study but is an issue of particular important to institutional investors (see for instance, Elliot and Halliday, 1996 and PRICOA, 1998). Finally, we produce data for 51 developed and emerging countries, whereas the study by Chen and Hobbs (2003) only cover 44 countries.

In summary, from a review of the previous studies that have tried to characterise the differences in international real estate markets it appears that there a number of dimensions that needed to considered by investors when trying to gauge a countries investment potential; the expected growth and risk of the country in general and real estate market's transparency and specific risk characteristics. The following section measures these dimensions of investment potential on a consistent and comparable basis for over 50 countries across the world.

\section{The Fundamental Dimensions of International Real Estate Investment}

\section{Expected Growth}

Given the lack of consistent and reliable international real estate returns data we estimate the expected returns of each country's real estate market by the taking the average expected growth rate in real GDP over the next five years from the Global Market Information Database.

\section{Country Risk}

Government actions affect real estate investment decisions everywhere. Even in domestic markets investors must deal with the potential for governmental actions like

1 For instance, Chen and Hobbs (2003) use the data from Gwartney et al (2001) for the legal structure of each country while we use Property Rights (PR) index by Johnson and Sheehy (1995) in conjunction with the "rule of law index" developed by La Porte et al (1997). 
rent controls; asbestos removal; hazardous waste cleanup, and tax law changes, all of which affect the value of real estate (Baum and Crosby, 1988). However, in foreign countries, the investor faces all of the preceding domestic risks and more: ranging from differences in cultural, valuation methods and local working practices. Thus, in their rush to capitalise on the opportunities of international real estate investment; many investors are stepping into the unknown. But no one likes the unknown so in order to narrow the odds with respect to the social and political context means reducing the country risk faced by the investor. In other words, an assessment of country risk is an essential criterion in international real estate investment decisions.

However, very little has been done to examine the effects of country risk on international portfolio investment. One reason for this may be the common misconception that country risk is relevant only to investment in less developed countries and not for developed nations. However, this is only true if country risk is defined solely in terms of political risk, which is often considered as one and the same as country risk. Political risk measures are based on factors such as frequency of changes in the government; conflicts with other countries; violence; armed insurrections; failure to meet international debt obligations; and so on. In other words, political risk indexes attempt to give the investor a relative measure of a government's potential longevity and its ability to stand by its foreign investment guarantees. However, country risk is a much broadly concept than simply political risk. Country risk not only includes the effects of political conditions; but economic conditions; discriminatory tax regulations; limitations on foreign ownership; lack of information; capital controls; and transactions costs. As such country risk becomes important enough to bear explicit recognition even when international investment is restricted to developed nations.

Hence, variables other than political stability are needed to be included in a measure of country risk. These frequently include the rate of inflation, the countries balance-ofpayment deficits or surpluses, and the growth rate of GNP per capita. Since, if a government is likely to run into trouble in any of these areas, it may attempt a "quick fix" by expropriating foreign-owned property or limiting the repatriation of profits to increase the government's revenues or improving its balance of payments position by introducing exchange controls. Hence, the better a country's economic outlook the less likely it is to face political and social turmoil. In other words, in developing an international diversification strategy investors need a measure of country risk that encompasses all factors that in some way limit market access or encumbers the normal investment process.

Of specific interest to international investors is the size of the premiums that international investment commands over domestic investment after country risk has been taken into account, i.e. the "hurdle rate" attached to real estate investment in different countries. This has been the approach of a few papers in the real estate literature. For example, Jones Lang LaSalle (JLL) (2000); Liang and McIntosh (2000) and Dockser et al (2001) all estimate the hurdle rates of countries by examining the risk premium of local bond rates to the US risk-free rate. The JLL approach takes a categorisation approach, whereby various risk premia are assigned to political risk, economic risk, real estate 
market risk, legal risk, and currency risk for various countries. Then by building up the risk premia from these components, JLL compute total hurdle rates or return for various countries. Liang and McIntosh (2000) estimate the risk premia across countries using the countries equity market return together with the country credit score to calculate the link between country risk and expected return. Dockser et al (2001) extents these approaches and looks at a host of economic and political variables that may affect the spread. Dockser et al (2001) finds that while many of these variables are highly correlated with the spread over the US T-Bills, they are also highly correlated with each other. Thus, starting with the country risk of each country, which alone explains over $60 \%$ of the variance in the spread, adding the other variables related to economic and political risk, did not improve the equation, and in fact resulted in the added variables being nonsignificant. Dockser et al (2001) concluding that as measures of country risk already accounts for many of these other factors a measure of country risk alone can be used to classify the risk of countries and hence the hurdle rate required for international real estate investment. In this study therefore we use a measure of country risk to estimate the risk premium required for investment into overseas markets.

A number of country risk services (CRS) exist. Such CRS provide a standardized method of comparing countries against various criteria in order to determine the relative scale of these risks and require an intimate understanding of both the quantitative and qualitative factors that determine the level of risk present when investing overseas. Among the CRS are the International Country Risk Guide; Business Environment Risk Intelligence; Economist Intelligence Unit; Institutional Investor and Euromoney, each of which is described in great detail by Coplin, and O’Leary (1994).

The International Country Risk Guide (ICRG) provides reports for 100 countries on a quarterly basis. Each report assesses potential economic, financial, and political risks to business investments and trade. The Economist Intelligence Unit (EIU) publishes country risk reports that are available quarterly with monthly updates. These reports summarise the risk ratings for 100 key emerging and highly indebted countries. The EIU risk rating methodology examines two different types of risk: (1) country risk, as determined by political (22\%), economic policy (28\%), economic structure (27\%), and liquidity (23\%) factors; and (2) specific investment risk. Three different types of specific investment risk are currency risk (associated with accepting foreign exchange exposure against the US dollar), sovereign debt risk (associated with foreign currency loans to sovereign states), and banking sector risk (associated with foreign currency loans to banks). The Institutional Investor (II) compiles semi-annual country risk surveys, which are based on responses provided by leading international banks. Bankers from 75-100 banks confidentially rate more than 135 countries on a scale of 0 to 100, with 100 representing the lowest risk. The individual ratings are weighted using an undisclosed formula, with greater weights assigned to responses based on the extent of a bank's worldwide exposure and the degree of sophistication of a bank's country risk model. The II country risk surveys are published in the March and September issues of the monthly magazine. Similarly, the Euromoney Country Risk (ECR) index provides semi-annual country risk ratings and rankings. Countries are given their respective scores based on nine components. The overall country risk score is then obtained byassigning the 
following weights to each of the nine categories (political risk, 25\%; economic performance, 25\%; debt indicators, $10 \%$; debt in default or rescheduled, $10 \%$; credit ratings, $10 \%$; access to bank finance, $5 \%$; access to short-term finance, $5 \%$; access to capital markets, 5\%; and discount on forfeiting, 5\%). The best underlying value per category achieves the full weighting, while the worst scores zero. All other values are calculated relative to the best and worst scores. Surveys are published in the March and September issues of this monthly magazine. We use the ECR in this paper as it is easy to collect the data and covers all the countries in this study and more. Nonetheless, we recognise that the ECR rankings have some shortcomings; first they are based on objective and subjective assessment and second the possibility of double counting in some categories (Buckley, 1992).

\section{Transparency}

The free flow of information to all participants is a necessary condition for market efficiency. However, access to information on the investment characteristics of commercial real estate markets varies greatly from country to country. An important specific issue is transparency, i.e. the ability of market participants to observe the information driving the trading process, (O'Hara, 1995). Hence, Brounen et al (2001) argue that transparency matters to investors.

If market transparency can be defined as the ability to receive correct and timely information about one's investment in another country, a country will be deemed to be more transparent when investment activities are conducted with a high level of integrity; in a political safe environment and where financial discloses are clear and meaningful. Thus, a more transparent market will foster confidence and trust and so should result in better decision-making, which as Fons (1998) notes, leads to "lower overall funding costs and higher profits." In contrast, a lack of transparency diminishes the reputation and credibility of its real estate market and increases significantly the cost of capital destined for a particular county (Gordon, 1999).

Low transparency is frequently considered to be synonymous with corruption ${ }^{2}$. For instance, Shang-Jin Wei (1997) concluded that investors choose less corrupt - more transparent - economies in which to invest, supportive of the arguments of Lee (2001, 2004). Shang-Jin Wei (1997) also suggests that corruption has the same deterrent effect on investment as increased taxes. For instance, Shang-Jin Wei (1997) shows that if the corruption level in Singapore was raised to the level of Mexico - it would be equivalent to increasing the tax rate on the foreign investor by more than $20 \%$. However, a transparent market is not only about freedom from corruption; it is also about the availability of information and the efficiency of the market. However, while measures of transparency

\footnotetext{
${ }^{2}$ Lee (2004) finds a significant correlation of 0.91 between the level of corruption in a country, as measured by the 2004 Transparency International Corruption Perception (CPI) Index and the level of real estate transparency, as measured by the 2004 Global Real Estate Transparency (GRET) Index produced by Jones Lang LaSalle (JLL), i.e. corruption thrives on a lack of transparency, which suggests that corruption is likely to be a problem in implementing any international diversification strategy, be it into developed or developing countries.
} 
of overall business environments, political risk and financial/accounting systems are currently available in most global markets, information regarding the transparency of real estate markets was until recently harder to come by until Jones Lang LaSalle (JLL) produced their Global Real Estate Transparency (GRET) Index in 1999.

The GRET index is based on a structured survey conducted within LaSalle Investment Managers (LIM) of their global network of researchers and covers the following five key attributes of real estate transparency: (1) Legal factors; (2) Regulatory burden; (3) Availability of information on market fundamentals; (4) Listed vehicle financial disclosure and governance; and (5) Availability of investment performance indexes.

Questions were developed for each attribute and countries assigned a score of 1 to 5, with " 1 "representing the highest level of transparency and " 5 "the lowest level of transparency. A composite index was then calculated by using a neutral weighting scheme. The composite scores range between 1 and 5 . A country with a perfect 1.00 would be the country with the highest level of transparency. A country with a total of 5.00 would be a country with total opacity ${ }^{3}$. From this data countries are assigned a composite GRET index and grouped into five broad tiers of transparency:

Tier 1: Highly Transparent

Tier 2: Transparent

Tier 3: Semi-Transparent

Tier 4: Low Transparency

Tier 5: Opaque ${ }^{4}$

We use the JLL GRET Index for 2004 to measure the transparency of the 51 countries examined here.

\section{Real Estate Market Specific Risk}

Because of the immobility of real property and the complexity of real estate transactions, a property investor needs more legal protection and stronger property rights than bond and equity investors. Thus, it seems reasonable to hypothesise that specific local factors exert a larger influence on overseas real estate investment decisions than for other international asset markets (D’Arcy and Keogh, 1994; Guerts and Jaffe, 1996; Jaffe and Louziotis, 1996; and Shun, 2004).

In order gauge the market specific risk of the local real estate market we collected data on a wide variety of property specific factors such as size, tax issues, and so on. First we estimate the investable market size of each country by initially adopting the approach of Ling and McIntosh (2000), which relates the size of the countries real estate market to the

\footnotetext{
${ }^{3}$ JLL also compile sub-indices for each of the five major attributes, however, since each sub-index is based on the answers to only two or three questions, JLL do not publish the sub-index rankings.

${ }^{4}$ Of the countries not covered in the JLL GRET index most, if not all, would fall into the opaque category. They have not been included in this analysis as JLL suggest that they do not feature in the investment plans of most international investors, lenders, developers or occupiers.
} 
countries GDP. We then adjusted these data to account for a number of factors foreign investors may encounter when investing in real estate, compared to local market players, so as to derive the countries investable or effective market size, which is likely to be considerable smaller (see DTZ, 2004). The first adjustment we made was designed to reflect the stringency of land use, as measured by the level of urbanisation in the country, to represent the basic size of the country to accommodate a large real estate market (source: World Bank, 2003).

Second, countries differ considerably in their approaches to lease law and tenant rights. Many have established leasing guidelines that favour the tenant's rights over the landlord's. Although many countries limit such rights to residential real estate, a number have extended similar rights to commercial properties. For instance, in Brazil, early lease termination and automatic renewal rights are common in commercial leases. Furthermore, tenant rights often vary by product type within a country. Additionally, despite international efforts to reduce barriers to foreign investment, foreign ownership of real estate in many countries is often subject to specific domestic restrictions and prohibitions. In Mexico, for example, direct ownership of real estate by a foreign individual or entity is prohibited within 100 kilometres of the border and within 50 kilometres of the coastline. In order to measure the security of property rights and the effectiveness of contracts and leasers we use Property Rights (PR) index developed for the Heritage Foundation by Johnson and Sheehy (1995) in conjunction with the rule and enforcement of law, especial with respect to non payment and bankruptcy, from the work of La Porte et al (1997).

Finally, we adjusted the data to reflect the taxation and ownership issues relating to direct real estate investment (source: Price Waterhouse Coopers, 2005). This diverse dataset was then subjected to PCA to reduce the dimensionality to an overall index of market specific risk.

\section{The REP Index}

Using the most recent data which quantifies a country on the four dimensions of international real estate investment potential discussed above indices were created from the raw values by standardising the items and putting them into a scale of 1 to 100 . The original data are first transformed into standardised data, or z-scores, to enable us to directly compare variables with very different distributions before country comparisons are attempted. Finally, the four dimensions were combined into the Real Estate Potential (REP) Index by neutrally weighting the four individual scores. To avoid the effects of variance of each dimension on the final index, the figures used to calculate the 1-100 scales for each dimension were again standardized; and converted into a 1-100 scale to establish the overall REP index.

However, while the equally-weighted REP Index presents a starting point for comparing international real estate markets, it does have limitations and real estate investors need to use some care in applying the index. First, the REP Index is an aggregate measure of a countries' real estate market investment potential and so should only be used in a broad 
impressionistic ways to qualifying and compare countries. For instance, it may be more appropriate to apply different weights for certain investors than the neutral weighting scheme used here. For example, private equity funds, who are probably more concerned with high expected returns may wish to add greater emphasis to the countries growth prospects, whereas investors who are usually more risk avers may place greater weight on the countries risk rating and level of transparency. Additionally, which countries which look most attractive from a Hong Kong or Singaporean investor perceptive might not be the same as for French or UK investors, as a result of cultural and language differences.

Second, when the investment process is about to be undertaken, much more detailed and in-depth analysis is required. For example, the decision as to whether the investment to be done directly or indirectly or whether to enter the market individually or with a local partner or through a joint venture, as such investors may need to examine additional factors.

Third, although the dimensions discussed here provide a comprehensive characterisation, alternative measures may need to be considered. For example, a more explicit representation of country risk may need to be examined as this is imbedded in the political risk measure from Euromoney, which may not be a good proxy for future real estate market growth.

Fourth, investors should also be constantly aware or cognisant of major macroeconomic events or country-specific developments that can cause readjustments to the REP index values. A final caveat about the reliability of the statistics used needs to be addressed as although the most credible sources and most recent available data were used, as with any data set, there is always room for improvement.

With these stated limitations in mind, the REP Index should be capable of providing real estate investors with valuable insights into the nature of international real estate markets. In particular, the REP index is perhaps most useful for gaining insight about individual international real estate markets in a comparative sense as the index reduces the complexity of evaluating the relative attractiveness of different countries to a few manageable dimensions. With this knowledge of the tradeoffs involved in choosing among countries, investors can be more objective and systematic in selecting candidate real estate markets. As once the number to be investigated is reduced to a manageable few, investors can then conduct an in-depth analysis of the most promising countries and concentrate on the next levels of investigation; the property-types to invest in and method of market entry. However, measuring risk factors is a trade-off between building a matrix that can capture all the risks inherent in an investment decision and acquiring data that is manageable and quick to use. In other words, while the REP index is a useful device for analysing the investment potential of global real estate markets it should never be employed as the only factor in decision making. Be that as it may, the REP index can help investors develop their international investment strategy by reducing the complex and bewildering array of data to a management size that the investor can focus on. The summary results of the analysis are presented in Table 1. 
Table 1: The Growth, Risk, Transparency and Market Specific Indexes and the REP Index for 51 Countries: 2004

\begin{tabular}{|c|c|c|c|c|c|}
\hline Country & $\begin{array}{c}\text { Expected } \\
\text { Growth } \\
\end{array}$ & $\begin{array}{c}\text { Country } \\
\text { Risk }\end{array}$ & Transparency & $\begin{array}{c}\text { Market } \\
\text { Specific Risk } \\
\end{array}$ & REP \\
\hline $\begin{array}{l}\text { 1. USA } \\
\text { 2. Ireland } \\
\text { 3. UK } \\
\text { 4. Canada } \\
\text { 5. France } \\
\text { 6. Australia } \\
\text { 7. Singapore } \\
\text { 8. Hong Kong } \\
\text { 9. Germany } \\
\text { 10. New Zealand } \\
\end{array}$ & $\begin{array}{c}\text { Average } \\
\text { Excellent } \\
\text { Average } \\
\text { Average } \\
\text { Weak } \\
\text { Average } \\
\text { Average } \\
\text { Good } \\
\text { Poor } \\
\text { Average } \\
\end{array}$ & $\begin{array}{c}\text { Excellent } \\
\text { Excellent } \\
\text { Excellent } \\
\text { Average } \\
\text { Good } \\
\text { Good } \\
\text { Excellent } \\
\text { Excellent } \\
\text { Good } \\
\text { Good } \\
\end{array}$ & $\begin{array}{l}\text { Excellent } \\
\text { Excellent } \\
\text { Excellent } \\
\text { Excellent } \\
\text { Excellent } \\
\text { Excellent } \\
\text { Excellent } \\
\text { Excellent } \\
\text { Excellent } \\
\text { Excellent } \\
\end{array}$ & $\begin{array}{c}\text { Excellent } \\
\text { Good } \\
\text { Excellent } \\
\text { Good } \\
\text { Excellent } \\
\text { Good } \\
\text { Good } \\
\text { Good } \\
\text { Excellent } \\
\text { Good } \\
\end{array}$ & $\begin{array}{l}\text { Excellent } \\
\text { Excellent } \\
\text { Excellent } \\
\text { Excellent } \\
\text { Excellent } \\
\text { Excellent } \\
\text { Excellent } \\
\text { Excellent } \\
\text { Excellent } \\
\text { Excellent }\end{array}$ \\
\hline $\begin{array}{l}\text { 11. Sweden } \\
\text { 12. Spain } \\
\text { 13. Japan } \\
\text { 14. Finland } \\
\text { 15. Netherlands } \\
\text { 16. Switzerland } \\
\text { 17. Denmark } \\
\text { 18. Austria } \\
\text { 19. Belgium } \\
\text { 20. Norway }\end{array}$ & $\begin{array}{c}\text { Average } \\
\text { Average } \\
\text { Poor } \\
\text { Average } \\
\text { Weak } \\
\text { Poor } \\
\text { Poor } \\
\text { Weak } \\
\text { Weak } \\
\text { Weak } \\
\end{array}$ & $\begin{array}{c}\text { Excellent } \\
\text { Average } \\
\text { Excellent } \\
\text { Good } \\
\text { Excellent } \\
\text { Excellent } \\
\text { Excellent } \\
\text { Excellent } \\
\text { Excellent } \\
\text { Excellent }\end{array}$ & $\begin{array}{l}\text { Excellent } \\
\text { Good } \\
\text { Good } \\
\text { Excellent } \\
\text { Excellent } \\
\text { Excellent } \\
\text { Excellent } \\
\text { Excellent } \\
\text { Excellent } \\
\text { Good } \\
\end{array}$ & $\begin{array}{l}\text { Excellent } \\
\text { Good } \\
\text { Excellent } \\
\text { Good } \\
\text { Good } \\
\text { Excellent } \\
\text { Excellent } \\
\text { Excellent } \\
\text { Good } \\
\text { Good } \\
\end{array}$ & $\begin{array}{l}\text { Good } \\
\text { Good } \\
\text { Good } \\
\text { Good } \\
\text { Good } \\
\text { Good } \\
\text { Good } \\
\text { Good } \\
\text { Good } \\
\text { Good }\end{array}$ \\
\hline $\begin{array}{l}\text { 21. Korea } \\
\text { 22. Malaysia } \\
\text { 23. Italy } \\
\text { 24. Taiwan } \\
\text { 25. Greece } \\
\text { 26. UAE } \\
\text { 27. Estonia } \\
\text { 28. China } \\
\text { 29. Portugal } \\
\text { 30. Hungary } \\
\text { 31. Thailand } \\
\text { 32. Russia }\end{array}$ & $\begin{array}{c}\text { Excellent } \\
\text { Excellent } \\
\text { Poor } \\
\text { Average } \\
\text { Good } \\
\text { Excellent } \\
\text { Excellent } \\
\text { Excellent } \\
\text { Poor } \\
\text { Good } \\
\text { Excellent } \\
\text { Excellent } \\
\end{array}$ & $\begin{array}{c}\text { Average } \\
\text { Weak } \\
\text { Good } \\
\text { Excellent } \\
\text { Average } \\
\text { Average } \\
\text { Weak } \\
\text { Average } \\
\text { Average } \\
\text { Weak } \\
\text { Weak } \\
\text { Poor } \\
\end{array}$ & $\begin{array}{c}\text { Average } \\
\text { Average } \\
\text { Average } \\
\text { Average } \\
\text { Average } \\
\text { Weak } \\
\text { Weak } \\
\text { Poor } \\
\text { Average } \\
\text { Weak } \\
\text { Weak } \\
\text { Poor } \\
\end{array}$ & $\begin{array}{c}\text { Average } \\
\text { Average } \\
\text { Good } \\
\text { Average } \\
\text { Average } \\
\text { Poor } \\
\text { Poor } \\
\text { Poor } \\
\text { Average } \\
\text { Average } \\
\text { Weak } \\
\text { Poor } \\
\end{array}$ & $\begin{array}{l}\text { Average } \\
\text { Average } \\
\text { Average } \\
\text { Average } \\
\text { Average } \\
\text { Average } \\
\text { Average } \\
\text { Average } \\
\text { Average } \\
\text { Average } \\
\text { Average } \\
\text { Average } \\
\end{array}$ \\
\hline $\begin{array}{l}\text { 33. India } \\
\text { 34. Chile } \\
\text { 35. South Africa } \\
\text { 36. Ukraine } \\
\text { 37. Vietnam } \\
\text { 38. Israel } \\
\text { 39. Poland } \\
\text { 40. Czech Republic } \\
\text { 41. Costa Rica } \\
\text { 42. Egypt }\end{array}$ & $\begin{array}{c}\text { Excellent } \\
\text { Average } \\
\text { Average } \\
\text { Excellent } \\
\text { Excellent } \\
\text { Weak } \\
\text { Average } \\
\text { Weak } \\
\text { Good } \\
\text { Good } \\
\end{array}$ & $\begin{array}{c}\text { Weak } \\
\text { Weak } \\
\text { Poor } \\
\text { Poor } \\
\text { Poor } \\
\text { Average } \\
\text { Weak } \\
\text { Weak } \\
\text { Weak } \\
\text { Poor } \\
\end{array}$ & $\begin{array}{c}\text { Poor } \\
\text { Average } \\
\text { Average } \\
\text { Poor } \\
\text { Poor } \\
\text { Average } \\
\text { Weak } \\
\text { Weak } \\
\text { Weak } \\
\text { Poor } \\
\end{array}$ & $\begin{array}{c}\text { Poor } \\
\text { Average } \\
\text { Weak } \\
\text { Poor } \\
\text { Poor } \\
\text { Average } \\
\text { Average } \\
\text { Average } \\
\text { Poor } \\
\text { Poor } \\
\end{array}$ & $\begin{array}{l}\text { Weak } \\
\text { Weak } \\
\text { Weak } \\
\text { Weak } \\
\text { Weak } \\
\text { Weak } \\
\text { Weak } \\
\text { Weak } \\
\text { Weak } \\
\text { Weak } \\
\end{array}$ \\
\hline $\begin{array}{l}\text { 43. Mexico } \\
\text { 44. Philippines } \\
\text { 45. Saudi Arabia } \\
\text { 46. Indonesia } \\
\text { 47. Romania } \\
\text { 48. Brazil } \\
\text { 49. Turkey } \\
\text { 50. Colombia } \\
\text { 51. Argentina }\end{array}$ & $\begin{array}{c}\text { Weak } \\
\text { Average } \\
\text { Weak } \\
\text { Average } \\
\text { Average } \\
\text { Poor } \\
\text { Weak } \\
\text { Poor } \\
\text { Poor }\end{array}$ & $\begin{array}{l}\text { Weak } \\
\text { Poor } \\
\text { Weak } \\
\text { Poor } \\
\text { Poor } \\
\text { Poor } \\
\text { Poor } \\
\text { Poor } \\
\text { Poor }\end{array}$ & $\begin{array}{l}\text { Weak } \\
\text { Poor } \\
\text { Poor } \\
\text { Poor } \\
\text { Poor } \\
\text { Poor } \\
\text { Poor } \\
\text { Poor } \\
\text { Poor }\end{array}$ & $\begin{array}{l}\text { Average } \\
\text { Weak } \\
\text { Poor } \\
\text { Weak } \\
\text { Poor } \\
\text { Average } \\
\text { Weak } \\
\text { Weak } \\
\text { Poor }\end{array}$ & $\begin{array}{l}\text { Poor } \\
\text { Poor } \\
\text { Poor } \\
\text { Poor } \\
\text { Poor } \\
\text { Poor } \\
\text { Poor } \\
\text { Poor } \\
\text { Poor }\end{array}$ \\
\hline
\end{tabular}

Table 1 presents the individual results of the Growth, Risk, Transparency, and Market Specific indexes along with the REP index for the 51 countries ranked by their overall REP score. In classifying the performance of each country on each dimension and for the REP index we adopted the following criteria; > 1x standard deviations: Excellent, 0.5 to $1 \mathrm{x}$ standard deviations: Good, -0.5 to $0.5 \mathrm{x}$ standard deviations: Average, $<-0.5$ to $-1 \mathrm{x}$ standard deviations: Weak, and $<1 \mathrm{x}$ standard deviations: Poor. 
Of all the countries sampled Argentina ranks the lowest because of its poor ratings on all dimensions. A position it is likely to maintain due to continued low acceptance of government's debt-restructuring plan, which means that its prolonged debt crisis may continue for years to come. The country with the highest REP index is the US, which ranks first on most criteria apart from growth.

The surprise is the position of Ireland, Germany and Japan. In the case of Ireland its second position overall is manly due to its excellent economic growth; country risk and transparency. However, the size of the market is still so small that investors will have difficulty in obtaining access. While, the relatively lowly position of Germany and Japan, both of which are two of the largest real estate markets in the world, is due to their poor economic prospects.

The position of Turkey, currently ranked as $49^{\text {th }}$ on the REP index is interesting in that it may well show a significant improvement as a result of the opening up of its' real estate markets in the future with its' accession into the European Union. Investors developing contacts or entering the market now in anticipation of such an improvement may well benefit in the future.

China is an interesting example of a country that should improve its current REP Index ranking $\left(28^{\text {th }}\right)$ as a result of the rapid introduction of modern banking and legal infrastructure. However, these changes may be diminished by a number of other features of the Chinese market. First, China is a country with weak "rule of law" that is particularly burdensome for foreign investors (Xin and Pearce, 1996). Second, the banking system in China, like every other Asian economy, is dealing with a mountain of none-performing loans which is likely to slow the liberalisation process down. Third, Luo (1997) and Tsang (1998) point out that foreign investor's must understand the unique business environment of personal relationships in China (often referred to as guanxi). Guanxi refers not only to possessing the same language and cultural traditions, but also to special links through relatives, friends, and former business ties in China. This suggests that investment in China is more likely to come from neighbouring countries with similar languages and cultures and family links such as Singapore and Hong Kong than from non-Chinese speaking countries, as this helps to mitigate the challenges posed in doing business in such an immature and opaque real estate market. In other words, although China's growth prospects are excellent unless the real estate fundamentals of the real estate market are improved it is likely to be still off-limits to cautious institutional investors, especially those lacking strong cultural and linguistic links.

The Czech Republic is an example of a country that has made structural changes in its economy to attract businesses and real estate investors from all over the world. In particular, depending upon their risk, tax, and capitalisation requirements, global investors in the Czech Republic can choose from a variety of ownership vehicles, including limited partnerships, limited liability companies, and joint stock companies. Additionally, lease provisions are fully negotiable and enforceable and real estate 
mortgages are common. Nonetheless, a present the Czech Republic is still ranked $40^{\text {th }}$ overall and must be considered a high risk investment.

A country of particular note is Singapore, which ranks first among far Eastern countries and $7^{\text {th }}$ overall due to its low country risk and high transparency, but which is weakened by its average growth over the past five years, which may be attributed to the SARs outbreak. The position of Singapore therefore should improve with a turn round in its economic performance as the impact of SARs is diminished. However, even though Singapore's market specifics are good the size of its real estate market will always remain small.

Russia now ranked as $32^{\text {nd }}$ overall, may fall even more if market liberalisation is reversed by the political regime. In the case of South Korea, ranked $21^{\text {st }}$, a major source of concern is the threat from North Korea. A renewed conflict between North and South would devastate both domestic and foreign investors and the possibility of such conflict never seems to be remote. Finally, the position of India $\left(33^{\text {rd }}\right)$ should get better with the improvements in its real estate market designed to attract more foreign investment (Wehner, 2005)

\section{Conclusion}

Real estate investors are slowly but surely moving overseas. The removal of barriers to entry, the adoption of global real estate standards, and develops in the legal and professional infrastructure mean that countries are in a better position than ever before to attract such investment capital. However, the lack of a consistent international real estate investment decision making methodology is still hindering the process. Global investors can help in driving this process forward by taking a consistent approach to the evaluation of international real estate markets. In other words, an effective international diversification strategy needs a consistent method of assessing the level of return required in each country taking into account not only historical developments but also views of future trends including economic and political factors. The work reported here develops and illustrates such a methodology for over 50 international real estate markets.

Based on an examination of previous studies an index was developed to measure real estate market potential in these countries using four facets which were chosen to characterise a country's attractiveness from the viewpoint of an institutional investor. These four variables represent the fundamental dimensions to consider when determining the overall attractiveness of a real estate market. From these four dimensions an overall index of REP was derived. The REP index developed here should therefore provide a number of insights into the essential aspects of international real estate market potential. In particular, the REP index can be used in two complimentary areas by investors; (1) the construction international real estate portfolios and (2) the classification of countries into opportunistic and core investment markets, both areas of which are currently been examined. 


\section{References}

AIG Global Real Estate Perspective (2001) Why Should Real Estate Investors Consider International Real Estate Investment?, AIG Global Real Estate Investment Corporation.

Arnold, H. R. and Grossman, C. (1995) International Real estate Investment: A Realistic Look at the Issues, in Pagliari, J.L. (ed) The Handbook of Real Estate Portfolio Management, Irwin

Baum, A and Crosby, B. (1988) Property Investment Appraisal, Routledge, London

Baum, A (1999) Changing Styles in International Real Estate Investment, Australian Land Economists Review, 5, 2, pp. 3-11.

Brounen, D. Cools, T.J.R., and Schweitzer, M. (2001) Information Transparency Pays: Evidence from European Property Shares, Real Estate Finance, Summer, 39-43

Buckley, A. (1992) Multinational Finance, Prentice Hall, London.

Chen, J. and Hobbs, P. (2003) Global Real Estate Risk Index, The Journal of Portfolio Management, Special Real Estate Issue, 66-75

Coplin, W.D. and O'Leary, M.K. (1994) The Handbook of Country and Political Risk Analysis, East Syracuse, New York: Political Risk Services, International Business Communications.

Chua, A. (1999) The Role of International Real Estate In Global Mixed-Asset Investment Portfolios, Journal of Real Estate Portfolio Management, 5, 2, 129-137.

D’Arcy, E. and Keogh, G. (1998) Territorial Competition and Property Market Process: an Exploratory Analysis, Urban Studies, 35, 8, 1215-1220.

D'Arcy, E. and Lee S.L. (1998) European Real Estate Portfolio Strategies: A Review of the Options, The Journal of Real Estate Portfolio Management, 3, 2, 113-123.

Del Casino, J.J., (1986) European Investment in US Office Markets, The Appraisal Journal,

Dockser, B.H., Rosen, K.T. and Van Dyke, D.T. (2001) Hurdle rates for International Real estate, Institute for Fiduciary Education, 3/01

DTZ (2004) Money into Property 
Elliot C. and Halliday R. (1996), The Institutional View of European Property Investment, A Paper Presented at 'The Cutting Edge’ Conference.

Euromoney, various issues

Fons, J.S. (1998) Improving Transparency in Asian Banking Systems, presented at the conference sponsored by the Federal Reserve Bank of Chicago and the International Monetary Fund titled: Asia: An Analysis of Financial Crisis, October.

Global Market Information Database, www.euromonitor.com

Gordon, J.N. (1999) Rising Market Efficiency: Property Enters the Mainstream, Property Futures, Jones Lang LaSalle, 2-9.

Guerts, T.G. and Jaffe, A.J. (1996) Risk and Real Estate Investment: An International perspective, The Journal of Real Estate Research, 11, 2, 117-130.

Gwartney, J., Lawson, R., Park, W. and Skipton, C. (2001) Economic Freedom of the World: 2001 Annual Report, Fraser Institute

Henderson Investors/AMP (2000) The Case for Global Property Investment, London: Henderson Investors Limited.

Hsien-hsing Liao and Jianping (J.P.) Mei (1999) Institutional Factors and Real Estate Returns - A Cross Country Study, International Real Estate Review, 2, 1, 21-34

Jaffe, A. and Louziotis, D. Jr. (1996) Property Rights and Economic Efficiency: A Survey of Institutional Factors, Journal of Real Estate Literature, 4, 2, 137-159

Jones Lang LaSalle (2000) Investment Strategy Annual

Jones Lang LaSalle (2004) Real Estate Transparency Index

Johnson, B.T. and Sheehy, T. (1995) The Index Of Economic Freedom (Washington, DC The Heritage Foundation.

Kateley, R. (2002) Managing International Risk: Practical Considerations for Direct Investors, PREA Quarterly, 14, 1, pp. 31-35.

Keogh, G. and D’Arcy, E. (1994) Market Maturity and Property Market Behaviour: A European Comparison of Mature and Emergent Markets, Journal of Property Research, 11, 215-35.

La Porta, R., Lopez-de-Silanes, F. Shleifer, A. and Vishny, R. (1997) Law and Finance, working paper No 5661, National Bureau of Economic Research. 
Lee, S.L. (2001) The Risks of Investing in the Real estate Markets of the Asian Region, Working Paper, University of Reading

Lee, S.L. (2004) Local Market Risk, in the Investment Property Forum (IPF) Handbook on International Real Estate

Levine M.L. (2004) International Real Estate: A Comparative Approach, Dearborn

Liang, Y. and W. McIntosh, W. (2000) Country Risk Premiums for International Investing, Prudential Securities

Liao, H. and Mei, J.P. (1999) Institutional Factors and Real Estate - A Cross Country Study, International Real Estate Review, 2, 1, 21-34

Lonie, A.A., Power, D.M. and Sinclair, C.D., The Putative Benefits of International Portfolio Diversification: A review of the Literature, British Review of Economic Issues, 15, 1993, 1-43.

Luo, Y. (1997) Guanxi and Performance of Foreign-invested Enterprises in China: An Empirical Inquiry, Management International Review, 37, 1. 51-70

Madura, J. (1985) International Portfolio Construction, Journal of Business Research, 13, 87-95

O’Hara, M. (1995) Market Microstructure Theory, Basil Blackwell Inc., Boston

Pagliari, J.L., Webb, R., Canter, T.A. and Lieblich, F. (1997) A Fundamental Comparison of International Real Estate Returns, Journal of Real Estate Research, 13, 2, 317-347

PriceWaterhouseCoopers (2005), Tax and Legal Guides for Real Estate Investors

PRICOA, (1998) The Institutional Real Estate Letter

Prudential Insurance Company of America/JLW (1988) A Comparison of International Real Estate Returns, London and New York: Prudential Insurance Company of America / Jones Lang Wootton

Prudential Real estate Investors (1990) Global Watch Report, Newark NJ: Prudential Real Estate Investors

Shun, C.K.L. (2004) An Empirical Investigation of the Role of the Legal Origin on the Performance of Property Stocks, Unpublished PhD Henley management Collage, Brunel University

Sirmans, C. and Worzala, E. (2000) International Direct Real Estate Investment: A Review of the Literature, Urban Studies, 40, 5, 1081-1114 
Sweeney, F. (1988) International Real Estate Diversification - A Viable Investment Strategy, Property Management, 5, 4, 317-326.

Sweeney, F. (1989) Investment Strategy: A Property Market Without Frontiers, Estates Gazette, 20-30

Sweeney, F.M. (1993) A European Property Investment Strategy, Journal of Property Valuation and Investment, 11, 3, 259-67

Tsang, E. (1998) Can Guanxi be a source of Sustained Competitive Advantage for doing Business in China? The Academy of Management Executive, 12, 2, 64-73

Webb, B and O’Keefe, J. (2002) The Case for Global Real Estate, Working paper published by UBS Global Asset Management

Wei, Shang-Jin (1997) How Reluctant are Nations in Global Integration? Unpublished, Kennedy School of Government, Harvard University

Whener, P. (2005) A Passage to India, Estates Gazette, 12 March, 51-53

Wilson, P. and Zurbruegg, R, (2003) International Diversification of Real Estate Assets Is it Worth It? Evidence from the Literature, Working Paper Series 126, School of Finance and Economics, University of Technology, Sydney

World Bank (2003) Sustainable Development in a Dynamic World: Transforming Institutions, Growth and Quality of Life, World Bank and Oxford University Press, pp. 108-110.

Worzala, E. (1994) Overseas Property Investments: How are they Perceived by the Institutional Investor? Journal of Property Valuation and Investment, 12, 3, 31-47.

Worzala, E. and Bernasek, A. (1996) European Economic Integration and Commercial Real Estate Markets: An Analysis of Trends in Market Determinants, Journal of Real Estate Research, 11, 2, 159-81

Xin, K. and Pearce, J. (1996) Guanxi: Connections as Substitute for Formal Institutional Support, Academy of Management Journal, 39, 6, 1641-1658 